\title{
Hot Summer Shines Light on Diagnosis of Pseudo-Bartter Syndrome
}

\author{
Vasanthan Tanigasalam ${ }^{1}$ (1) $\cdot$ Kirti Naranje $^{1} \cdot$ Rajat Ahuja $^{1} \cdot$ Aakash Pandita $^{1} \cdot$ Girish Gupta $^{1}$
}

Received: 28 July 2019 / Accepted: 21 November 2019 / Published online: 20 December 2019

(C) Dr. K C Chaudhuri Foundation 2019

To the Editor: Cystic fibrosis manifesting as Pseudo-Bartter syndrome is a rare presentation. Pseudo-Bartter syndrome, as the initial presentation, is reported in $9 \%$ of cystic fibrosis infants. In patients over 1 year, $12 \%$ of cases have been reported [1]. We describe a one-month-old infant who got admitted with recurrent episodes of dehydration, electrolyte derangement and metabolic alkalosis due to excess of chloride loss from sweating. This unusual presentation is noted in cystic fibrosis infants during hot summer climate.

A 1-mo-old exclusively breastfed infant born to primigravida mother by non-consanguineous marriage was referred to our hospital due to severe dehydration, metabolic alkalosis, and electrolyte derangement. There was no family or antenatal history of infant deaths present. There was no previous comorbid illness present. At admission $\mathrm{pH}-7.56 ; \mathrm{HCO}_{3}-32$; sodium $-125 \mathrm{mmol} / \mathrm{L}$ and potassium $-2.1 \mathrm{mmol} / \mathrm{L}$ was found. The chest X-ray suggested right upper lobe collapse. There was no history of diarrhea, vomiting or polyuria explaining the severe dehydration noted. Hence at admission, the reason underlying Pseudo-Bartter syndrome and lung collapse was not known. The metabolic alkalosis and electrolyte derangement gradually resolved with severe dehydration correction and hence the infant was discharged and planned for followup. The infant was noted to develop recurrent episodes of mild to moderate dehydration, metabolic alkalosis and electrolyte derangement (Pseudo-Bartter syndrome) within $2 \mathrm{wk}$ of discharge. Hence dehydration due to insensible water losses in the form of sweating was considered. This raised the suspicion

Vasanthan Tanigasalam

vasanthan2k6jipmer@gmail.com

1 Department of Neonatology, Sanjay Gandhi Post Graduate Institute of Medical Sciences (SGPGI), Lucknow, Uttar Pradesh, India of cystic fibrosis, which was supported by the persistence of lung collapse in X-ray, low plasma chloride ( $55 \mathrm{mmol} / \mathrm{L})$, low urine chloride $(8.9 \mathrm{mmol} / \mathrm{L})$, high sweat chloride levels $(70 \mathrm{mmol} / \mathrm{L})$ and normal blood pressure $(65 / 40 \mathrm{mmHg})$. Genetic mutation for the delta F508 gene was negative. The infant was treated with oral rehydration solution and nebulization for lung collapse management. The treatment followup plan during infancy includes additional sodium intake during hot weather, weight gain monitoring, and immunization (influenza and pneumococcal vaccine).

Cystic fibrosis presenting like Pseudo-Bartter syndrome is a rare entity. These infants are initially asymptomatic but later develop dehydration and Pseudo-Bartter syndrome [2]. The presence of thick viscid secretions predisposes to lung collapse in these infants [3]. Hence one should suspect cystic fibrosis when there is chloride responsive dehydration, metabolic alkalosis and low urine chloride levels due to chloride losses from sweating in hot summer climate [4].

\section{Compliance with Ethical Standards}

Conflict of Interest None.

\section{References}

1. Faraji-Goodarzi M. Pseudo-Bartter syndrome in children with cystic fibrosis. Clin Case Rep. 2019;7:1123-6.

2. Vilotijević-Dautović G, Stojanović V. Pseudo-Bartter's syndrome in patients with cystic fibrosis: a case series and review of the literature. Srp Arh Celok Lek. 2015;143:748-51.

3. Sankaran K, Kalapurackal M, Wiebe S. Cystic fibrosis: an unusual neonatal presentation. Pediatr Pulmonol. 2012;47:620-2.

4. Soifer JT, Kim HT. Approach to metabolic alkalosis. Emerg Med Clin North Am. 2014;32:453-63.

Publisher's Note Springer Nature remains neutral with regard to jurisdictional claims in published maps and institutional affiliations. 